\title{
Stakeholder approach, Stakeholders mental model: A visualization test with cognitive mapping technique
}

\author{
Garoui Nassreddine* and Jarboui Anis
}

Faculty of Economics and Management (FSEG), Higher Institute of Business Administration (ISAAS) Postal Address: ISAAS - 3018 Sfax-Tunisia

\begin{tabular}{l}
\hline A R T I C L E I N F O \\
\hline Article history: \\
Received September 2, 2011 \\
Received in Revised form \\
January, 12, 2011 \\
Accepted 14 January 2012 \\
Available online \\
14 January 2012 \\
\hline Keywords: \\
Corporate governance \\
Stakeholder model \\
Cognitive mapping
\end{tabular}

\section{A B S T R A C T}

\begin{abstract}
The idea of this paper is to determine the mental models of actors in the firm with respect to the stakeholder approach of corporate governance. The use of the cognitive map to view these diagrams to show the ways of thinking and conceptualization of the stakeholder approach. The paper takes a corporate governance perspective, discusses stakeholder model. It takes also a cognitive mapping technique.
\end{abstract}

(c) 2012 Growing Science Ltd. All rights reserved.

\section{Introduction}

One way to help overcome the limitations of shareholder model is the approach proposed by Charreaux and Desbrières (1998). It consists the stakeholder model and it integrates all the stakeholders who contribute to create value. From the perspective of contractual approaches, the firm is conceived as a production team that creates value (the organizational rent) through synergies between the different factors of production.

Evolution, in relation to the shareholder model is at the distribution of value: the rent sharing is extended to all participants in the nexus of contracts. The underlying assumption is that the parties 'production factor' will be encouraged to contribute to the creation of value only if they receive a portion of the rate. In this sense, corporate governance only affects the creation and the distribution of value. It is akin to a set of rules governing the ex post bargaining that takes place between the partners to share the rent (Zingales, 1998). The theory of the firm specialized (Demsetz, 1988) has the advantage of providing a link with the cognitive theories. It allows to exceed the fixed view of the stakeholder model 'standard' by trying to integrate the dynamic productive.

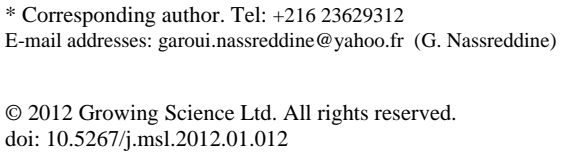


However, like many other approaches, it remains insufficiently explanatory factors for understanding how all the actors that constitute an organization are likely to capture the issues of corporate social responsibility.

\section{Literature review}

\subsection{The stakeholder model turns to all stakeholders}

The notion of stakeholder has been deepened by Freeman (1984) which defines stakeholder as any individual or group that could influence or be influenced itself by the organizational activity, "a stakeholder in a organization is (by definition) Any group or individual who can affect or is affected by the achievement of the organization's objective". Schematically, this concept is represented by a circle whose center is the company and stakeholders, the radii (Freeman and Reed, 1983; Freeman, 1984). Each group represented in a bubble is biased, a stake (a stake) in the company, hence the name of a party, a holder of issue (stakeholder). New institutional sociological theory shows the importance of the institutional environment in understanding the behavior of organizations (Capron, \& QuairelLanoizelée, 2004). The conditions of the environment cannot be separated from the perception of the actors, Weick (1969) in his theory of enaction says that it is the managers' decisions that give meaning and construct reality: the parties stakeholders are in fact staged and defined by the importance given to them by the leaders (Capron, \& Quairel-Lanoizelée, 2004). There are two diametrically opposed visions of CSR. The minimalist view of Friedman (1970) which reduces CSR at the sole economic responsibility. For him the responsibility of a company is limited to profit maximization for shareholders. Conversely, the purists of the stakeholder theory of CSR include requests for all social groups that are directly or indirectly affected by the activities of the company.

The word stakeholder is composed of stake, in other words, the interests or claims that an individual or group carries on the business. These stakes of the stakeholders are not always obvious or explicit (Weiss, 1998) but the goal is to show that the partners other than shareholders have a stake in the company, the term stakeholders or "stakeholders" has undoubted heuristic value (Cazal \& Dietrich, 2005).

\subsection{The key concepts of the stakeholder approach}

\section{Value creation and abandonment of the opportunity as exogenous}

If we adopt this vision for value creation, one of the most important problems is to develop an appropriate vision of the future. This means abandoning the traditional assumption in finance that all opportunities would be an exogenous and objective, to make way for an approach that some opportunities are created of authentic leaders. Charreaux (2000) concludes that the cognitive perspective leads to a reinterpretation of the role of directors, rather than just supervisors, may "help the manager to build his vision - by comparing the mental models of the directors - or at detect, if not to build growth opportunities ".

\section{The firm as a specific investment node}

Most of the partnership approach is to challenge the exclusive status of residual claimant and owner to shareholders. It must be extended to all parts of the nexus of contracts involved in the creation of value because it is not fair to say that only shareholders suffer a cost when they discontinue their relationship with the company. Managers can be encouraged to increase their personal investment in specific human capital, thus creating additional value. Too much discipline may reduce the incentive for effort and initiative. The managerial rents may decrease. Employees, neglected in the standard approach, are being rethought as a specific asset. They develop skills and know-how are not transferable to other firms and they may lose on the termination of the contract. The same is true for providers who develop cooperative relations with 
their principal and who face bankruptcy in the event of breach of contract. All parties bear the risks associated with their specific investments. To be encouraged to specialize, so they should participate in the sharing of the surplus. (Blair,1995). The firm is under Rajan and Zingales (1998) a "nodespecific investments, that is to say" a combination of assets and people each specialty. "These investments accumulate around a specific skill" critical ", the manager. It exercises control over all the stakeholders. It influences the accumulation of assets and attempts to implement the complementarities between the resource and managerial expertise of other persons.

\section{Multiple accountability: power and legitimacy}

The boundary facing the application of agency theory is its bipolarity: the confrontation between managers and shareholders defines space power as the result of a set of calculations based on the transfer of information to the market. The leader, a sovereign space associated with its expertise in management, shareholders, an evaluation space, associated with the level of profit is their pay according to their residual claim. However, this bipolarity is bursting with the ownership of mass, the rise of institutional and, more generally, the new form of economy of corporate finance. First, the notion of shareholders' interests must be carefully considered depending on the nature of shareholders, their time horizons and their power relations on the other hand, the legitimacy of the leader is challenged for his expertise in management is now shared by financial analysts, rating agencies when it is not the journalists or advice "proxies".

The agency relationship involved a clear separation of responsibilities for functions and calculations can be done to separate between principal and agent, as distinct skills. This is where the sovereign power made sense. With its crumbling, it would then consider an agency theory more complex; the principal-agent relationships are different in nature according to the shareholders who are now as diverse as the stakeholders of the company. Become complex and systemic (Charreaux, 1997), modeling of behavior depending on a variety of interests is not compatible with the framework imposed by the bipolar model of the agency. Clearly, a government in power management "controlled", that is to say, involving both the rationale for decisions and their effective control, with responsibility taken split into multiple actors.

\section{Maximizing profit and residual claim}

If, as we have seen, the new deal gives the agenda the issue of "private ownership of means of production," it poses to the agency theory, academically dominant, considerable problems.

For the theory to work effectively, it is assumed that the conflict between shareholders and managers can balance the responsibilities effective managerial firm as it defines the sovereign power of the leader. This hypothesis assumes that shareholders have a behavior function based on maximizing the profit from their residual claim on the company.

\subsection{Stakeholder value and independence to the pension and distribution}

This presentation of the stakeholder value, consistent with the definition of rent (or quasi-rent) can highlight certain features of the organizational game:

- The manager creates value if the difference between the sales prices of opportunity and opportunity costs is positive. In this sense, to increase value creation, the leader must act simultaneously on the prices and opportunity costs. The price level depends on whether the scarcity of particular goods and services offered by the firm and dependency of clients in relation to it. A strong innovation is often an important source of value creation, all things being equal. Symmetrically, the creation of value can also go through a lower opportunity cost, for example, to pay any required by lenders due to a lower risk or a partnership agreement with suppliers reduces the risk of opportunism. 
- The conditions underlying the Coase theorem is not met, value creation is not independent of the distribution. Rent (Ricardian rent or annuity or efficiency) for a provider of resources is equal to the additional compensation received from the minimum compensation required for the establishment of the transaction, and it appreciates against the entry cooperation. It is normally linked to the scarcity factor. Thus, an officer receives a pension if his salary is higher than the earnings opportunity, this supplement is linked to the scarcity of managerial skills meant to create more value.

\section{Conflict of interest in contractual theories}

Theories assume that organizations contractual relations between actors are Potentially Responsible for conflicts to explain the establishment of governance mechanisms. These are, indeed, to channel the actions of the leader (Charreaux, 1997), so as to reduce the extent of deviant behavior. The result is a theoretical efficiency gain, because governance is to reduce the costs associated with behaviors that originate from divergent interests. The confrontational nature of relations between partners of the firm is a central premise of contract theory to explain the phenomena of GE.

\section{Information asymmetry}

The phenomenon of information asymmetry is the result of the delegation of management of the company to professional managers. Naturally, information held by the agent is more relevant than that held by the shareholders to the extent that the leader acts as the operational management. Contracts signed by both parties are necessarily incomplete, because it is impossible ex ante to predict all situations that may arise.

Indeed, according to Arrow (1965), information asymmetry gives rise to two phenomena. The first "adverse selection", or adverse selection concerns the uncertainty about the quality or characteristics of the object of an exchange that led to the possibility of fraud, because they can be expected by victims potential lead to complex strategies to protect themselves. In this situation, the shareholder does not necessarily have any useful information to define precisely the contract. The second "moral hazard" concerns situations in which one side of the market can observe the behavior of the other.

\section{The agency theory}

The separation of ownership and the decision suggested by Berle and Means (1932), if understandable in the Anglo-Saxon system, characterized by high dispersion of ownership among several small shareholders, it "appears if not erroneous, at least incomplete "for the French context (Charreaux, 2006).

According Charreaux (2006), "the emphasis on the role of provider of financing led shareholders to question the centrality accorded to them since the share of investment financed by capital increases financial markets is minimal."

\section{The theory of the roots}

The theory of the roots was developed by Morck, Vishny and Shleiffer in the late1980. It is based on the premise of active behavior of the leader whose goal is "to destroy or weaken the control mechanisms set up by the shareholders or stakeholders" (Allouche \& Amann, 2002). Leaders try to implement strategies of influence "... to increase their discretionary space using the means at their disposal, that is their human capital but also the company's assets, to neutralize the systems control and increase the dependence of all the partners of the firm to the resources they control (specific human capital, information asymmetry) Alexander (2000). Rooting assumes that the means of control and incentive of the manager are not perfectly efficient in the firm, but also that the leader adopts an opportunistic behavior. 


\section{Research Methodology}

\subsection{Methodological tools}

We used an approach for measuring the performances of the actors of the company by using a common technique in cognitive approaches, which is a cognitive mapping. This is a graphical modeling technique of cognition used in numerous studies in management sciences.

The cognitive map is not only a tool for analyzing the managerial cognition, but also it is the most popular for the presentation of cognitive structures.

Cognitive mapping is a technique now well established capture the minds of the players about a problem or situation. A cognitive map allows us to view certain ideas and beliefs of an individual on a complex area such as corporate governance. A cognitive map is usually defined as the graphical representation of a person's beliefs about a particular field.

A map is not a scientific model based on an objective reality, but a representation of a part of the world as seen by an individual.

\subsection{Description of the empirical investigation}

To meet the research objectives mentioned above, a survey was conducted among players in the company of Tunisia. We have chosen as exploratory approach using multiple case studies. The multiple case studies seek a better understanding of the phenomenon. They are to study a phenomenon in its natural setting by working with a limited number of cases. They are particularly interesting in the case of exploration of little-known phenomena. The case studies thus allow multiple accounts the specificities and characteristics of corporate governance. The data come from 10 firms. The decision to base our study on a sample of firms from various sectors is based on the assumption that a variety of issues will be addressed as well.

The output is a cognitive map for actors reflecting their perceptions on the stakeholder approach of corporate governance. The method used to create cognitive maps is the questionnaire.

\subsection{Presentation of the questionnaire}

The questionnaire is divided into two parts: the first identifies the company and the second deals with corporate governance. For the second part, relating to corporate governance, we interview actors from the firm on stakeholder approach of corporate governance by providing a list of concepts for each approach with systematic exploration grids and matrices cross.

\section{Systematic exploration of the grid is a technique for collecting materials}

Each player is encouraged to explore his/her own ideas or cognitive representations in relation to its strategic vision. The subject is asked to identify important factors, which would have an impact on the key concept related to an approach to corporate governance.

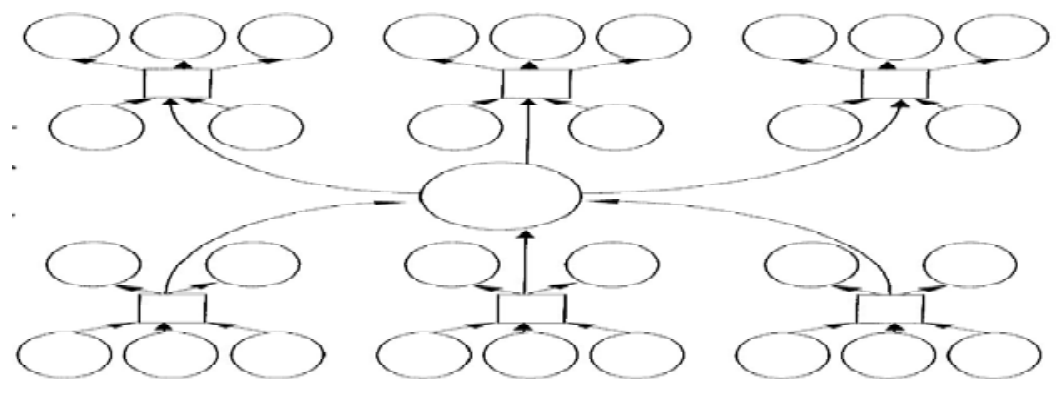

Fig. 1. Grid systematic exploration 
Regarding the cross-matrix, it is also a technique of data collection and the basis for the construction of the cognitive map. The matrix is presented in the form of a table with $n$ rows and n columns. Box of index $(i, j)$ indicates the relationship between concept $i$ and concept $j$.

The actors manipulate the key concepts and assign pairs of concepts depending on the nature and degree of proximity sensed between these concepts.

Table1

Adjacency matrix

\begin{tabular}{lllll}
\hline & Concept1 & Concep2 & $\ldots \ldots$ & Concept $\mathrm{n}$ \\
Concept1 & 1 & & & L2n \\
Concept2 & L21 & 1 & 1 & \\
$\ldots \ldots$. & & & & 1 \\
\hline Concept $\mathrm{n}$ & Ln1 & Ln2 & & \\
\hline
\end{tabular}

\subsection{Proposal for modeling cognitive maps}

When it is difficult to identify the goals, an integrated approach of performance provides a holistic view in which the performance is analyzed by the processes that lead, through the performances of the actors. These representation processes are two problems of implementation: the sharing of representations of actors and the identification of dominant representations in the organization in order to act upon them (Halgand, 1999).

The construction of this representation necessarily requires a model that allows understanding to act is "an action of intentional design and construction, for composition of symbols, patterns that would make a complex phenomenon intelligible perceived.

In this context, the use of cognitive maps seems relevant, because they can take into account the complexity and comprehensiveness of the system in which [the behavior] is embedded, while maintaining access to the analysis (Komocar, 1994, p.157). The value of the tool is instrumental (Audet, 1994), it allows both improving their actions and making sense.

Cognitive mapping is used as a tool for representation of an idiosyncratic schema (Cossette, 1994), a pattern is "a cognitive structure that guides the cutting of reality, the interpretation of events, and action individuals ", pattern unique to each individual, causing it to have its own behavior.

\subsection{The construction of cognitive maps}

We will see at first step that allowed the construction of concepts, methodological approach that we discuss. Then we will examine how the cards were dealt.

\section{Concepts}

We addressed this issue by the representations constructed by players using the method of cognitive maps, a method that can be applied to poorly structured situations. An analysis based on cognitive maps can understand this process of structuring, as this model is to build or rebuild the mental simultaneously modeling. This construction takes the form of a structure, carrier for clarification.

It helps to identify ways to implement to achieve a given goal, the same way it helps to identify the goals justifying the use of such means. Finally, it facilitates communication and negotiation. There are two major trends in the construction method of the cards: the determination of the concepts can be ex ante, or subsequent interviews with respondents for whom the cards are built. Komocar (1994) links the question of determining nodes - or concepts - and links to two paradigms. In the 
phenomenological paradigm, the universe is largely unknown. The emphasis is on describing the world from the experiences of people who experience it.

Nodes and links are determined directly by the participants that advocate Cossette and Audet (1994), not to deprive the subject of representations: the questions should be invitations for the respondent verbalizes his thoughts on what he considers important subject of research (Cossette, 1994). In addition, the researcher cannot force the subject to consider every possible link because the links must be made spontaneously or in response to open questions, so that the subject constructs its reality (Cossette and Audet, 1994). In the normative paradigm, the universe is more or less determined. The focus is on operational definitions and research plans reproducible. Observers, different participants, may determine the relationship between variables and nodes that can be.

Komocar proposes to take account of these two paradigms by adopting the following position: the nodes are determined a priori, and the links between these nodes are determined by the participants (Bougon et al., 1977; Komocar, 1994; Markoczy, 2001). We selected 19 concepts for the partnership approach to their ability to describe the field of governance. We were guided in this by a literature review and an exploratory study based on a questionnaire made up of grids of systematic exploration and cross-matrices. The concepts presented in the table below.

\section{Table2}

Key concepts for stakeholder approach

\begin{tabular}{ll}
\hline 1)Creating value (CV) & 11)Annuity (R) \\
2)Opportunity (opp) & 12)Distribution (Rep) \\
3)Contract node (Nc) & 13)Conflict (C) \\
4)Specific Investment (inv sp) & 14)Asymmetric information (AI) \\
5)Specific human capital (C H S) & 15)Property (prop) \\
6)Responsibility multiple (Res Mul) & 16)Decision (D) \\
7)Power (pou) & 17)Dispersion of property (Dis pro) \\
8)Legitimacy (Leg) & 18)Business strategy (S Ese) \\
9)Profit (pro) & 19)Business assets (A Ese) \\
10)Residual claim (C R) & \\
\hline
\end{tabular}

\section{Materials and methods of structural analysis}

Analysis of the results led initially by a preliminary investigation of perceptions that are players in the Tunisian company vis-à-vis the stakeholder approach of governance.

This investigation was limited to the analysis of a collective cognitive map for all company, prepared on the basis of systematic exploration grids completed by the actors of the company.

From cognitive maps, we could identify and qualify the designs are the actors of the field of corporate governance. The development and analysis of cognitive maps were made using the Mic-Mac software.

Our initial investigation focused on two elements: the relative importance of concepts and analysis of the dynamics of influence / dependence concepts (or variables) in the cognitive universe of players in the company. The relative importance of concepts was evaluated from the MIC. Mic-Mac program allowed us to rank the concepts in order to "balance" and "dependency."Thus arise the ideas that dominate in the cognitive universe of players.

\subsection{Overview of structural analysis method}

The main objective of structural analysis is to identify the most important variables in determining the evolution of the system. 
Inspired by graph theory, structural analysis is based on the description of a system using a matrix linking all its components. By weighting these relationships, the method highlights the key variables to changes in the system. As a tool, we opted for the software "Micmac" (cross-impact matrices, Multiplication Applied to Classification). The first step of the method MICMAC is to identify all the variables characterizing the system under study (both external and internal variables). The second step involves the linking of variables in the construction of the matrix of direct influence and potential. Indeed, this approach is supported by the fact that in a systemic approach, a variable exists only through its network of relationships with other variables. It is from this matrix what has identified the key variables. Indeed, we obtain the classification by the direct sum row and column. If the total connections line indicates the importance of the influence of a variable on the overall system (direct motor level), the total column shows the degree of dependence of one variable (level of direct dependence).

The ranking against indirect detects hidden variables through a matrix multiplication program applied to indirect classification."This program allows us to study the distribution of impacts by the paths and feedback loops, and therefore to prioritize the variables in order of influence."

\subsection{Matrices and processing MICMAC method}

All structural analysis matrices above have been established only from direct relationships between variables. However, it is clear that a variable can also exert influence on other variables indirectly, or through another variable ("path" of order 2), or through several others exercising their influence cascaded through "paths" for longer and longer, and can also loop over themselves. The classification of motor skills may be significantly altered, and understanding the mechanisms of the system similarly. Establish direct relations matrices indirect paths of length two, then three ... then $\mathrm{N}$ would quickly become intractable. A relatively simple mathematical processing (multiplication of a matrix by itself, and elevation of the power matrices $\mathrm{N}$ ) solves this problem. Benefiting from the spread of computers and personal computer, the method MICMAC (cross-impact matrix-multiplication applied to classification) is a commercial version. As expected, the rankings of variables by motor / decreasing influence (or dependence) generally find it changed. But experience has shown that these rankings become almost stable after three or four students to the power, and they are clearly the importance of some new variables in terms of their indirect influences.

Map and analyzed at the collective level, the map is the collective model of mental representations of several people on a research topic identified. In some cases, the cards are developed by collective aggregation of individual cards and in other cases they are developed directly by building a group card. In the first case, the card is called collective and composite map is constructed by superimposing individual maps (Bougon \& Komocar, 1994; Bougon, 1977; Ford \& Hegarty, 1984). While in the second case, the cards are called strategic and more individuals come to gether to create a community card. It then seeks to map the shared perceptions of a group of individuals on a particular area. The strategy map is at the organizational level (Langfield-Smith, 1992). But how to decide in a strategic map? "When the goal is to make a collective card, a decision usually a link of influence unites two concepts when a significant number of subjects claim the presence of such a link" (Cossette, 2004).

\section{List of variables}

The following summarizes the list of variables used in this paper.

\begin{tabular}{lllll} 
List of variables & & & \\
\hline Creating value (CV) & Specific human capital (C H S) & Profit (pro) & Conflict (C) & Dispersion of property (Dis pro) \\
\hline Opportunity (opp) & Responsibility multiple (Res Mul) & Residual claim (C R) & $\begin{array}{l}\text { Asymmetric } \\
\text { information (AI) }\end{array}$ & Business strategy (S Ese) \\
\hline Contract node (Nc) & Power (pou) & Annuity (R) & Property (prop) & Business assets (A Ese) \\
\hline Specific Investment (inv sp) & Legitimacy (Leg) & Distribution (Rep) & Decision (D) & \\
\hline
\end{tabular}


The input

This step was to compile a matrix of direct influence between these variables in a scoring session. Matrix of direct influence (MID) which describes the relationship of direct influence between the variables defining the system and the Matrix Influences MIDP represents the potential direct influences and dependencies between existing and potential variables. The scoring has developed the input matrix "matrix of direct influences (MID). The influences are rated from 0 to 3, with the ability to report potential influences.

\subsection{Matrix of direct influences (MID)}

Matrix of direct influence (MID) describes the relationship of direct influences between the variables defining the system.

Table 3

Matrix of direct influences

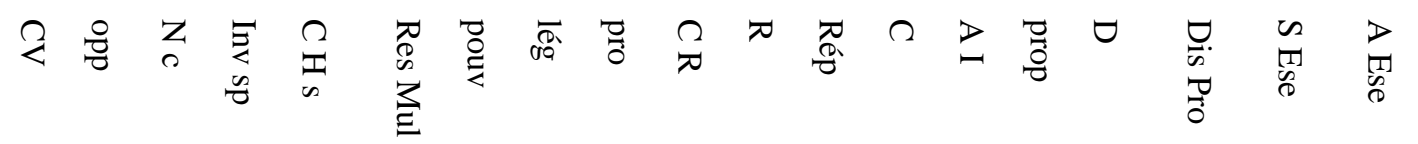

\begin{tabular}{llllllllllllllllllll} 
CV & 0 & 1 & 0 & 2 & 0 & 3 & 0 & 1 & 0 & $\mathrm{P}$ & 0 & 2 & 0 & 0 & 2 & 0 & 1 & 0 & 0 \\
Opp & 1 & 0 & 0 & 0 & 0 & 0 & 0 & 0 & 0 & 0 & 0 & $\mathrm{P}$ & 0 & 0 & 0 & 2 & 0 & 0 & 0 \\
N C & 0 & 0 & 0 & 0 & 0 & 0 & 0 & 0 & 0 & 0 & 0 & 0 & 0 & 0 & 1 & 0 & 1 & 0 & 0 \\
Inv sp & 2 & 0 & 0 & 0 & 0 & 0 & 2 & 0 & 0 & 0 & 0 & 0 & 0 & 3 & 0 & 0 & 0 & 2 & 0 \\
C H S & 0 & 0 & 0 & 0 & 0 & 0 & 0 & 0 & 0 & 1 & 0 & 0 & 0 & 0 & 0 & 0 & 2 & 0 & 0 \\
Res Mul & 3 & 0 & 2 & 0 & 0 & 0 & 0 & 0 & 0 & 0 & 0 & 0 & 2 & 0 & 0 & 0 & 3 & 0 & 0 \\
Pou & 0 & 0 & 0 & 2 & 0 & 0 & 0 & 0 & 0 & 0 & 0 & 0 & $\mathrm{P}$ & 0 & 0 & 0 & $\mathrm{P}$ & 0 & 3 \\
Lég & 1 & 0 & 3 & 0 & 0 & 0 & 0 & 0 & $\mathrm{P}$ & 0 & 0 & 0 & 0 & 0 & 0 & 1 & 0 & 0 & 0 \\
Pro & 0 & 0 & 0 & 0 & $\mathrm{P}$ & 0 & 0 & 0 & 0 & 0 & 0 & 1 & 0 & 0 & 0 & 0 & 0 & 0 & 0 \\
C R & $\mathrm{P}$ & 0 & 0 & 0 & 1 & 0 & 0 & 3 & 0 & 0 & 0 & 0 & 0 & 2 & 0 & 0 & $\mathrm{P}$ & 0 & 0 \\
R & 0 & 0 & 0 & 0 & 2 & 0 & 0 & 0 & $\mathrm{P}$ & 0 & 0 & 0 & 0 & 0 & 0 & 1 & 0 & 0 & 2 \\
Rép & 2 & 0 & 0 & 1 & 0 & 0 & 0 & 0 & 0 & 0 & 0 & 0 & 3 & 1 & 0 & 0 & 0 & 0 & 0 \\
C & 0 & 0 & $\mathrm{P}$ & 0 & 0 & 3 & 0 & 0 & 0 & 2 & 0 & 0 & 0 & 0 & 0 & 0 & 1 & 0 & 1 \\
A I & 0 & 0 & 0 & 1 & 0 & 0 & 0 & $\mathrm{P}$ & 0 & 0 & 0 & 0 & 0 & 0 & 1 & 0 & 0 & 0 & 0 \\
Prop & 0 & 0 & 3 & 0 & 0 & 0 & 0 & 0 & 0 & 0 & 0 & 3 & 0 & 1 & 0 & 0 & 0 & 0 & 0 \\
D & 0 & 0 & 0 & 0 & 0 & 0 & 0 & 0 & 1 & 0 & 1 & 0 & 0 & 0 & 1 & 0 & 0 & 0 & 0 \\
Dis Pro & 1 & 0 & 2 & 0 & 1 & 0 & 0 & 0 & 0 & 0 & 0 & 0 & 0 & 0 & 0 & 0 & 0 & 0 & 2 \\
S Ese & 0 & 0 & 0 & 1 & 0 & 0 & 0 & 2 & 0 & 0 & 0 & 0 & 0 & 0 & 0 & $\mathrm{P}$ & 0 & 0 & 0 \\
A Ese & 0 & 0 & 0 & 0 & 0 & 3 & 0 & 0 & 0 & $\mathrm{P}$ & 0 & 0 & 0 & 0 & 2 & 0 & 0 & 0 & 0 \\
\hline
\end{tabular}

The influences are rated from 0 to 3 , with the ability to report potential influences:
0: No influence
1: Low
2: Average
3: Strong
P: Potential

\subsection{Matrix of direct potential influences (MIDP)}

The Matrix Influences MIDP represents the potential direct influences and dependencies between existing and potential variables. It complements the matrix MID also taking into account possible relationships in the future. 
Table 4

Matrix of potential direct influences

\begin{tabular}{|c|c|c|c|c|c|c|c|c|c|c|c|c|c|c|c|c|c|c|c|}
\hline & 2 & 윰 & \begin{tabular}{l} 
Z \\
\hdashline
\end{tabular} & $\begin{array}{l}\Xi \\
\dot{z} \\
\text { on }\end{array}$ & $\begin{array}{l}\Omega \\
\text { I } \\
\text { I }\end{array}$ & 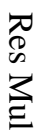 & 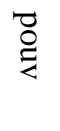 & হ্ম & ס & $\Omega$ & $\varnothing$ & 总 & $\Omega$ & $D$ & 뭉 & $\bullet$ & $\begin{array}{l}\underset{W}{\sigma} \\
\varpi \\
0\end{array}$ & $\begin{array}{l}\omega \\
\text { 㽣 }\end{array}$ & $\begin{array}{l}D \\
\stackrel{D}{D} \\
\stackrel{D}{D}\end{array}$ \\
\hline $\mathrm{CV}$ & 0 & 1 & 0 & 2 & 0 & 3 & 0 & 1 & 0 & 3 & 0 & 2 & 0 & 0 & 2 & 0 & 1 & 0 & 0 \\
\hline Opp & 1 & 0 & 0 & 0 & 0 & 0 & 0 & 0 & 0 & 0 & 0 & 3 & 0 & 0 & 0 & 2 & 0 & 0 & 0 \\
\hline N C & 0 & 0 & 0 & 0 & 0 & 0 & 0 & 0 & 0 & 0 & 0 & 0 & 0 & 0 & 1 & 0 & 1 & 0 & 0 \\
\hline Inv sp & 2 & 0 & 0 & 0 & 0 & 0 & 2 & 0 & 0 & 0 & 0 & 0 & 0 & 3 & 0 & 0 & 0 & 2 & 0 \\
\hline C H S & 0 & 0 & 0 & 0 & 0 & 0 & 0 & 0 & 0 & 1 & 0 & 0 & 0 & 0 & 0 & 0 & 2 & 0 & 0 \\
\hline Res Mul & 3 & 0 & 2 & 0 & 0 & 0 & 0 & 0 & 0 & 0 & 0 & 0 & 2 & 0 & 0 & 0 & 3 & 0 & 0 \\
\hline Pou & 0 & 0 & 0 & 2 & 0 & 0 & 0 & 0 & 0 & 0 & 0 & 0 & 3 & 0 & 0 & 0 & 3 & 0 & 3 \\
\hline Lég & 1 & 0 & 3 & 0 & 0 & 0 & 0 & 0 & 3 & 0 & 0 & 0 & 0 & 0 & 0 & 1 & 0 & 0 & 0 \\
\hline Pro & 0 & 0 & 0 & 0 & 3 & 0 & 0 & 0 & 0 & 0 & 0 & 1 & 0 & 0 & 0 & 0 & 0 & 0 & 0 \\
\hline C R & 3 & 0 & 0 & 0 & 1 & 0 & 0 & 3 & 0 & 0 & 0 & 0 & 0 & 2 & 0 & 0 & 3 & 0 & 0 \\
\hline $\mathrm{R}$ & 0 & 0 & 0 & 0 & 2 & 0 & 0 & 0 & 3 & 0 & 0 & 0 & 0 & 0 & 0 & 1 & 0 & 0 & 2 \\
\hline Rép & 2 & 0 & 0 & 1 & 0 & 0 & 0 & 0 & 0 & 0 & 0 & 0 & 3 & 1 & 0 & 0 & 0 & 0 & 0 \\
\hline $\mathrm{C}$ & 0 & 0 & 3 & 0 & 0 & 3 & 0 & 0 & 0 & 2 & 0 & 0 & 0 & 0 & 0 & 0 & 1 & 0 & 1 \\
\hline A I & 0 & 0 & 0 & 1 & 0 & 0 & 0 & 3 & 0 & 0 & 0 & 0 & 0 & 0 & 1 & 0 & 0 & 0 & 0 \\
\hline Prop & 0 & 0 & 3 & 0 & 0 & 0 & 0 & 0 & 0 & 0 & 0 & 3 & 0 & 1 & 0 & 0 & 0 & 0 & 0 \\
\hline $\mathrm{D}$ & 0 & 0 & 0 & 0 & 0 & 0 & 0 & 0 & 1 & 0 & 1 & 0 & 0 & 0 & 1 & 0 & 0 & 0 & 0 \\
\hline Dis Pro & 1 & 0 & 2 & 0 & 1 & 0 & 0 & 0 & 0 & 0 & 0 & 0 & 0 & 0 & 0 & 0 & 0 & 0 & 2 \\
\hline S Ese & 0 & 0 & 0 & 1 & 0 & 0 & 0 & 2 & 0 & 0 & 0 & 0 & 0 & 0 & 0 & 3 & 0 & 0 & 0 \\
\hline A Ese & 0 & 0 & 0 & 0 & 0 & 3 & 0 & 0 & 0 & 3 & 0 & 0 & 0 & 0 & 2 & 0 & 0 & 0 & 0 \\
\hline
\end{tabular}

The influences are scored from 0 to 3 :
0 : No influence
1: Low
2: Average
3: Strong

\section{Results of the study}

\subsection{Direct influences}

\section{Characteristic of MID}

This table shows the number of $0,1,2,3,4$ of the matrix and displays the filling ratio calculated as the ratio between the number of MID values different from 0 and the total number of elements of the matrix.

\section{Table 5}

Characteristic of MID

\begin{tabular}{llllllllll}
\hline Indicator & $\begin{array}{l}\text { Size } \\
\text { matrix }\end{array}$ & $\begin{array}{l}\text { Number } \\
\text { iterations }\end{array}$ & $\begin{array}{l}\text { Number of } \\
\text { zero }\end{array}$ & $\begin{array}{l}\text { Numbre of } \\
\text { one }\end{array}$ & $\begin{array}{l}\text { Number of } \\
\text { two }\end{array}$ & $\begin{array}{l}\text { Number of } \\
\text { three }\end{array}$ & $\begin{array}{l}\text { Number of } \\
\text { P }\end{array}$ & $\begin{array}{l}\text { Total } \\
12\end{array}$ & $\begin{array}{l}\text { Fill rate } \\
13\end{array}$ \\
\hline Value & 19 & 2 & 291 & 25 & 20 & $19,39058 \%$ & 10 \\
\hline
\end{tabular}

\section{Stability from MID}

If it is shown that any matrix must converge to stability after a certain number of iterations (usually 4 or 5 for a matrix of size 30), it was interesting to monitor the stability during the successive multiplications. In the absence of established criteria mathematically, it was chosen to rely on the number of permutations (bubble sort) necessary to classify each iteration, influence and dependence, all the variables of the matrix MID.

\section{Table 6}

Stability from MID

\begin{tabular}{lll}
\hline Iteration & Influence & Dependence \\
\hline 1 & $90 \%$ & $98 \%$ \\
2 & $104 \%$ & $103 \%$ \\
\hline
\end{tabular}




\subsection{Sum of rows and columns of MID}

This table is used to enter the sums in row and column of the matrix MID

\section{Table 7}

Sum of rows and columns

\begin{tabular}{llll}
\hline $\mathrm{N}^{\circ}$ & Variable & Total of rows & Total of columns \\
\hline 1 & Value creating & 12 & 10 \\
2 & Opportunity & 3 & 1 \\
3 & Contract node & 2 & 10 \\
4 & Specific investment & 9 & 7 \\
5 & Specific human capital & 3 & 4 \\
6 & Responsibility multiple & 10 & 9 \\
7 & Power & 5 & 2 \\
8 & Legetimacy & 5 & 6 \\
9 & Profit & 1 & 1 \\
10 & Residual claim & 6 & 3 \\
11 & Annuity & 5 & 1 \\
12 & Distribution & 7 & 6 \\
13 & Conflict & 7 & 5 \\
14 & Asymetric information & 2 & 7 \\
15 & Property & 7 & 7 \\
16 & Decision & 3 & 4 \\
17 & Dispersion of property & 6 & 8 \\
18 & Business strategy & 3 & 2 \\
19 & Business assets & 5 & 8 \\
& Totals & 101 & 101 \\
\hline
\end{tabular}

potential direct influences

\subsection{Characteristic of MIDP}

This table shows the number of $0,1,2,3.4$ and MIDP matrix displays the filling ratio calculated as the ratio between the number of MID values different from 0 and the total number of elements of the matrix.

\section{Table 8}

Characteristic of MIDP

\begin{tabular}{ll}
\hline Indicator & Value \\
\hline Size of matrix & 19 \\
Number of iterations & 2 \\
Number of zero & 291 \\
Number of one & 25 \\
Number of two & 20 \\
Number of three & 25 \\
Number of P & 0 \\
\hline Total & 70 \\
\hline Fill rate & $19,39058 \%$ \\
\hline
\end{tabular}

\section{Stability from MIDP}

If it is shown that any matrix must converge to stability after a certain number of iterations (usually 4 or 5 for a matrix of size 30), it was interesting to monitor the stability during the successive multiplications. In the absence of established criteria mathematically, it was chosen to rely on the number of permutations (bubble sort) necessary to classify each iteration, influence and dependence, the set of variables. 
Table 9

Stability from MIDP

\begin{tabular}{lcc}
\hline Iteration & Influence & Dependence \\
\hline 1 & $93 \%$ & $91 \%$ \\
2 & $101 \%$ & $103 \%$ \\
\hline
\end{tabular}

Sum of rows and columns of MIDP

This table is used to enter the sums in row and column of the matrix MIDP.

Table 10

Sum of rows and columns

\begin{tabular}{|c|c|c|c|c|c|c|c|}
\hline $\mathrm{N}^{\circ}$ & Variable & Total of rows & Total of columns & $\mathrm{N}^{\circ}$ & Variable & Total of rows & Total of columns \\
\hline 1 & Value creating & 15 & 13 & 11 & annuity & 8 & 1 \\
\hline 2 & opportunity & 6 & 1 & 12 & distribution & 7 & 9 \\
\hline 3 & Contract node & 2 & 13 & 13 & conflict & 10 & 8 \\
\hline 4 & Specific investment & 9 & 7 & 14 & Asymetric information & 5 & 7 \\
\hline 5 & Specific human capital & 3 & 7 & 15 & property & 7 & 7 \\
\hline 6 & responsibility multiple & 10 & 9 & 16 & decision & 3 & 7 \\
\hline 7 & power & 11 & 2 & 17 & dispersion of property & 6 & 14 \\
\hline 8 & legetimacy & 8 & 9 & 18 & Business strategic & 6 & 2 \\
\hline 9 & profit & 4 & 7 & 19 & Business assets & 8 & 8 \\
\hline \multirow[t]{2}{*}{10} & Residual claim & 12 & 9 & & & & \\
\hline & & & & & Totals & 101 & 101 \\
\hline
\end{tabular}

\subsection{Indirect influences}

\section{Matrix of indirect influences(MII)}

The matrix of indirect influences (MII) is the matrix of direct influences (MID) high power, by successive iterations. From this matrix, a new classification of variables high lights the most important variables of the system. Indeed, it reveals the hidden variables through a matrix multiplication program applied to indirect classification. This program allows us to study the distribution of impacts by the paths and feedback loops, and therefore to prioritize the variables in order of influence, taking into account the number of paths and loops of length $1,2, \ldots, n$ from each variable in order of length, taking into account the number of paths and loops of length $1,2, \ldots n$ arriving on each variable. The ranking is stable in general from an increase in the order 3,4 or 5.

Table 11

Matrix of indirect influences

\begin{tabular}{|c|c|c|c|c|c|c|c|c|c|c|c|c|c|c|c|c|c|c|c|}
\hline & 2 & 윰 & ${ }_{2}^{z}$ & $\begin{array}{l}\text { 穴 } \\
\text { y }\end{array}$ & $\underset{n}{\Omega}$ & 坣恿 & '" & 可 & 뭉 & $\approx$ & $\not$ & 葸 & 0 & $D$ & "ृ & $\theta$ & $\begin{array}{l}\square \\
\text {. } \\
\text { to }\end{array}$ & 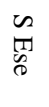 & $\begin{array}{l}D \\
\text { TI } \\
\text { D } \\
D\end{array}$ \\
\hline CV & 25 & 20 & 18 & 68 & 9 & 102 & 4 & 28 & 3 & 25 & 3 & 40 & 18 & 12 & 74 & 0 & 51 & 4 & 42 \\
\hline Opp & 20 & 0 & 23 & 2 & 5 & 0 & 4 & 0 & 0 & 0 & 0 & 14 & 12 & 12 & 0 & 5 & 9 & 4 & 6 \\
\hline N C & 6 & 1 & 0 & 6 & 0 & 9 & 0 & 1 & 0 & 1 & 0 & 2 & 9 & 3 & 12 & 0 & 8 & 0 & 0 \\
\hline Inv sp & 62 & 0 & 55 & 4 & 2 & 18 & 26 & 0 & 0 & 0 & 0 & 21 & 24 & 50 & 12 & 10 & 18 & 26 & 4 \\
\hline C H S & 3 & 2 & 9 & 6 & 0 & 18 & 0 & 2 & 0 & 3 & 0 & 4 & 00 & 0 & 18 & 3 & 12 & 0 & 0 \\
\hline Res Mul & 82 & 3 & 77 & 12 & 11 & 33 & 12 & 15 & 0 & 3 & 0 & 30 & 48 & 40 & 28 & 9 & 60 & 12 & 14 \\
\hline Pou & 27 & 4 & 36 & 26 & 0 & 12 & 0 & 12 & 0 & 0 & 0 & 26 & 18 & 6 & 14 & 0 & 31 & 0 & 12 \\
\hline Lég & 23 & 0 & 35 & 2 & 6 & 0 & 4 & 0 & 0 & 0 & 0 & 19 & 12 & 14 & 0 & 4 & 9 & 4 & 10 \\
\hline Pro & 2 & 2 & 0 & 5 & 0 & 15 & 2 & 2 & 0 & 6 & 0 & 4 & 0 & 3 & 5 & 0 & 5 & 2 & 3 \\
\hline C R & 6 & 3 & 10 & 6 & 3 & 9 & 4 & 6 & 3 & 0 & 3 & 12 & 0 & 10 & 18 & 0 & 12 & 4 & 4 \\
\hline $\mathrm{R}$ & 22 & 0 & 35 & 0 & 8 & 0 & 0 & 6 & 0 & 0 & 0 & 16 & 12 & 9 & 0 & 1 & 18 & 0 & 10 \\
\hline Rép & 72 & 2 & 61 & 17 & 11 & 15 & 10 & 24 & 0 & 0 & 0 & 19 & 42 & 36 & 13 & 6 & 47 & 10 & 16 \\
\hline C & 24 & 10 & 48 & 24 & 9 & 54 & 0 & 10 & 0 & 15 & 0 & 26 & 6 & 2 & 36 & 6 & 39 & 0 & 24 \\
\hline A I & 6 & 2 & 0 & 17 & 0 & 6 & 0 & 6 & 0 & 0 & 0 & 4 & 9 & 3 & 11 & 0 & 5 & 0 & 6 \\
\hline Prop & 11 & 6 & 18 & 15 & 3 & 45 & 8 & 6 & 0 & 18 & 0 & 24 & 0 & 16 & 15 & 0 & 15 & 8 & 15 \\
\hline $\mathrm{D}$ & 8 & 0 & 0 & 5 & 0 & 6 & 0 & 0 & 1 & 2 & 1 & 0 & 12 & 4 & 9 & 0 & 7 & 0 & 0 \\
\hline Dis Pro & 42 & 0 & 55 & 2 & 6 & 0 & 4 & 3 & 0 & 0 & 0 & 24 & 24 & 18 & 0 & 3 & 27 & 4 & 10 \\
\hline S Ese & 0 & 4 & 0 & 17 & 0 & 12 & 0 & 8 & 2 & 0 & 2 & 8 & 0 & 0 & 19 & 0 & 10 & 0 & 6 \\
\hline A Ese & 21 & 9 & 18 & 26 & 9 & 45 & 0 & 9 & 0 & 12 & 0 & 18 & 18 & 6 & 32 & 0 & 27 & 0 & 24 \\
\hline
\end{tabular}


The values represent the rate of indirect influences

Sum of rows and columns of MII

This table is used to enter the sums in row and column of the matrix MII.

Table 12

Sum of rows and columns

\begin{tabular}{|c|c|c|c|c|c|c|c|}
\hline $\mathrm{N}^{\circ}$ & Variable & Total of rows & Total of columns & $\mathrm{N}^{\circ}$ & Variable & Total of rows & Total of columns \\
\hline 1 & Value creating & 546 & 462 & 11 & annuity & 137 & 9 \\
\hline 2 & opportunity & 116 & 68 & 12 & dispersion & 401 & 311 \\
\hline 3 & Contract node & 58 & 498 & 13 & conflict & 333 & 264 \\
\hline 4 & Specific investment & 332 & 260 & 14 & asymetric information & 75 & 244 \\
\hline 5 & Specific human capital & 80 & 82 & 15 & property & 223 & 316 \\
\hline 6 & responsibility multiple & 489 & 399 & 16 & decision & 55 & 47 \\
\hline 7 & power & 224 & 78 & 17 & dispersion of property & 222 & 410 \\
\hline 8 & legitimacy & 142 & 138 & 18 & Business strategic & 88 & 78 \\
\hline 9 & profit & 56 & 9 & 19 & Business assets & 274 & 206 \\
\hline \multirow[t]{2}{*}{10} & Residual claim & 113 & 85 & & & & \\
\hline & & & & & Totals & 101 & 101 \\
\hline
\end{tabular}

\section{Potential indirect influences}

\section{Matrix of potential indirect influences (MIIP)}

The Matrix of Potential Indirect Influences (MIIP) is the matrix of direct influences Potential (MIDP) high power, by successive iterations.

From this matrix, a new classification of variables highlights the potentially most important variables of the system.

\section{Table 13}

Matrix of potential indirect influences

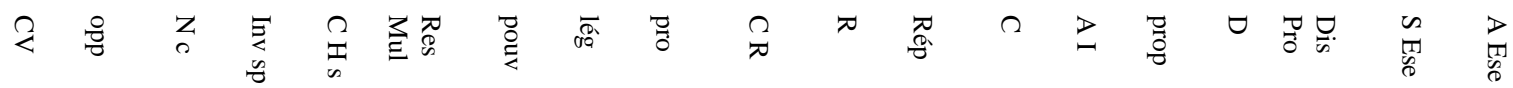

\begin{tabular}{lllllllllllllllllllll}
\hline CV & 49 & 29 & 99 & 95 & 27 & 129 & 4 & 85 & 30 & 121 & 3 & 61 & 39 & 15 & 98 & 21 & 78 & 4 & 60 \\
Opp & 35 & 6 & 50 & 17 & 14 & 45 & 10 & 24 & 9 & 36 & 0 & 29 & 12 & 27 & 15 & 5 & 33 & 10 & 15 \\
N C & 6 & 1 & 0 & 6 & 0 & 9 & 0 & 4 & 0 & 10 & 0 & 2 & 9 & 3 & 12 & 0 & 8 & 0 & 0 \\
Inv sp & 95 & 0 & 112 & 4 & 14 & 36 & 26 & 18 & 51 & 30 & 6 & 27 & 24 & 62 & 18 & 19 & 42 & 26 & 22 \\
C H S & 6 & 5 & 15 & 12 & 3 & 27 & 0 & 11 & 9 & 30 & 0 & 10 & 0 & 0 & 24 & 3 & 15 & 0 & 6 \\
Res Mul & 121 & 3 & 77 & 12 & 20 & 33 & 12 & 42 & 9 & 36 & 0 & 39 & 48 & 58 & 34 & 9 & 105 & 12 & 14 \\
Pou & 102 & 7 & 60 & 32 & 18 & 48 & 0 & 78 & 0 & 51 & 0 & 32 & 48 & 36 & 53 & 12 & 139 & 0 & 18 \\
Lég & 38 & 0 & 35 & 5 & 12 & 0 & 4 & 9 & 6 & 9 & 0 & 22 & 21 & 23 & 0 & 4 & 36 & 4 & 10 \\
Pro & 17 & 2 & 21 & 5 & 9 & 15 & 2 & 14 & 0 & 12 & 0 & 4 & 0 & 9 & 5 & 0 & 14 & 2 & 15 \\
C R & 102 & 6 & 79 & 18 & 42 & 36 & 16 & 36 & 30 & 39 & 3 & 54 & 36 & 58 & 42 & 15 & 84 & 16 & 10 \\
R & 52 & 0 & 35 & 3 & 17 & 0 & 0 & 24 & 3 & 9 & 0 & 16 & 21 & 24 & 0 & 1 & 60 & 0 & 10 \\
Rép & 11 & 2 & 70 & 17 & 17 & 15 & 10 & 51 & 15 & 15 & 0 & 25 & 48 & 48 & 22 & 15 & 98 & 10 & 16 \\
C & 42 & 16 & 93 & 36 & 21 & 72 & 0 & 37 & 18 & 69 & 0 & 47 & 6 & 11 & 48 & 6 & 54 & 0 & 42 \\
A I & 6 & 5 & 0 & 23 & 27 & 15 & 0 & 21 & 3 & 15 & 3 & 19 & 15 & 3 & 29 & 6 & 23 & 0 & 6 \\
Prop & 14 & 6 & 54 & 15 & 3 & 45 & 8 & 15 & 9 & 36 & 0 & 24 & 0 & 16 & 15 & 3 & 15 & 8 & 15 \\
D & 8 & 0 & 0 & 5 & 9 & 6 & 0 & 3 & 1 & 11 & 1 & 3 & 12 & 4 & 9 & 0 & 13 & 0 & 0 \\
Dis Pro & 72 & 0 & 55 & 2 & 15 & 0 & 4 & 30 & 3 & 0 & 0 & 27 & 24 & 36 & 0 & 3 & 57 & 4 & 10 \\
S Ese & 0 & 4 & 9 & 17 & 33 & 12 & 0 & 17 & 11 & 12 & 2 & 26 & 6 & 3 & 19 & 9 & 16 & 0 & 12 \\
A Ese & 39 & 18 & 81 & 50 & 18 & 72 & 0 & 42 & 27 & 69 & 0 & 36 & 18 & 6 & 56 & 9 & 42 & 0 & 42 \\
\hline & & & & & & & & & & & & & & & & \\
\hline
\end{tabular}

The values represent the rate of indirect potential influences.

Sum of rows and columns of MIIP 
Table 14

Sum of rows and columns

\begin{tabular}{|c|c|c|c|c|c|c|c|}
\hline $\mathrm{N}^{\circ}$ & Variable & Total of rows & Total of columns & $\mathrm{N}^{\circ}$ & Variable & Total of rows & Total of columns \\
\hline 1 & Value creating & 1047 & 915 & 11 & Annuity & 275 & 18 \\
\hline 2 & Opportunity & 392 & 110 & 12 & Distribution & 605 & 503 \\
\hline 3 & Contract node & 70 & 945 & 13 & Conflict & 618 & 387 \\
\hline 4 & Specific investment & 632 & 374 & 14 & $\begin{array}{l}\text { Asymetric } \\
\text { information }\end{array}$ & 219 & 442 \\
\hline 5 & Specific human capital & 176 & 319 & 15 & Property & 301 & 499 \\
\hline 6 & Responsibility multiple & 684 & 615 & 16 & Decision & 85 & 140 \\
\hline 7 & Power & 734 & 96 & 17 & $\begin{array}{l}\text { Dispersion of } \\
\text { property }\end{array}$ & 342 & 932 \\
\hline 8 & Legitimacy & 238 & 561 & 18 & Business strategic & 208 & 96 \\
\hline 9 & Profit & 146 & 234 & 19 & Business assets & 625 & 323 \\
\hline \multirow[t]{2}{*}{10} & Residual claim & 722 & 610 & & & & \\
\hline & & & & & Totals & 101 & 101 \\
\hline
\end{tabular}

\section{Conclusions and implications of the research}

Concepts (or variables) cognitive structuring the universe of players can be projected in terms of influence / dependence. The distribution of the point cloud variables in this plan, particularly in relation to different quadrants allow to distinguish four broad categories of variables. The first quadrant includes the most prominent concepts in the dynamics of the thought of the actors. For the actors of that organization, the notion of "conflict" is the most dominant in their cognitions reflecting an intention based on a partnership approach focused on conflicts of interest. Returning to the systematic exploration of grids for each actor, there is a balance of concepts expressing their orientation.

For example an actor, this concept is expressed through statements such as "property", "Judgement", "delegation." Thus reflecting an agency logic orientation.

In logic of agency, that is to say separation of ownership and decision-making and delegation of authority, the conflict is rooted in the possibility of agent behavior (leader) does not comply the interests of the principal (shareholder). One then finds the current practices of contestation of all power, both in its exercise of its legitimacy. The result is a cost of conflict management that it is latent or it bursts open. Assuming that individuals could live naturally in harmony, the establishment of governance structures would be meaningless.

For the actor 2, this orientation is expressed through statements such as "specialization", "organization", "targets", "production" reflecting a productive logic. Indeed, the increasing specialization in the firm is the origin of conflicting objectives and from this point of view, this view presents more similarities with the approaches "contract" with approaches that see the organization as "a cognitive community ". Thus, there is the idea that the firm is the headquarters of the opposition between different approaches, the organization of the firm consists of two dimensions: the organization of production whose function is efficient and productive sales organization whose function is to value the assets of the company by buying and selling. These two types of functions performed by the respective actors of the firm, may conflict because they are not established on the same criteria for evaluating economic efficiency. Industrial logic and logic have the same financial basis as they are of practices and habits of thought different. The first combines the richness in the production of use value on goods and services produced for the market, the second involves the creation of wealth in the monetary value of production (with the growth of external funding) in assets the company.

The second approach requires sometimes scarce production to support prices, slowing innovation to avoid the obsolescence of capital, and between and in opposition to the first while, conversely, support productivity and innovation can lead to overproduction or the devaluation of capital. 
Concepts related to the logic of agency resources are most cited by the players, tried explaining the concept of "conflict".

The second quadrant includes the relay variables that are by definition both very influential and very dependent. By analyzing the level of influence / dependence, there are players for the concepts or ideas that illustrate the concepts of "value creation", "multiple liabilities", "Specific Investment," "distribution" and "property". The ideas of the players in the Tunisian firms tend to focus on three basic concepts that are "owned", "investment" and "value creation".

In this sense, the performance results from the creation of wealth that comes from making an investment that creates value. This achievement depends on the ability of each individual involved in the investment process to derive a satisfactory gain.

This concept of extended value to different stakeholders has the interest to highlight that the creation of value not only the result of capital contributions by shareholders but the combined efforts of all partners. Different approaches to the creation of stakeholder value are possible. Charreaux and Desbrières (1998) propose a method for measuring stakeholder value creation, based on an overall measure of the rents created by the company in connection with the stakeholders and not just shareholders.

The third quadrant contains the dependent variables or resulting. They are both influential and very little dependent and therefore particularly sensitive. They are the result of which is explained by the variable motor and relay. Thus there are the high dependence of a number of factors such as the variables of legitimacy, information asymmetry and dispersion of ownership. The fourth quadrant includes the independent variables are simultaneously little influence and little dependent. They are relatively excluded from the dynamics of thinking by the company of Tunisia. The plan review influences / dependencies shows the existence of a number of independent variables such as variables related to the decision, business strategy, residual claim, profit, etc..

- The number of links of influence is an indicator of the degree of integration of the cognitive map.

- The degree of interconnection is an indicator of the density of the cognitive map. It can be calculated in a simple way by dividing the number of links (l) by the number of concepts (n) or more elaborate way by dividing the number of links present in the maximum number of possible links. According to Eden and Ackermann (1998), a level of integration such a cognitive map computed by the simple ratio ( $/ \mathrm{n}$ ) should be between 1.15 and 1.25.

Cossette (2004) to analyze the main aspect of the topography of a cognitive map from: The relative importance of each concept: from the number of concepts to which a concept is directly or indirectly connected. It seeks to assess the centrality of a concept in the discourse. We have, from the total, in line expressing the total weight of the variable influence, and column length.

\section{Table 15}

Total of rows and columns

\begin{tabular}{|c|c|c|c|c|c|c|c|}
\hline $\mathrm{N}^{\circ}$ & Variable & Total of rows & Total of columns & $\mathrm{N}^{\circ}$ & Variable & Total of rows & Total of columns \\
\hline 1 & Value creating & 12 & 10 & 11 & Annuity & 5 & 1 \\
\hline 2 & Opportunity & 3 & 1 & 12 & Distribution & 7 & 6 \\
\hline 3 & Contract node & 2 & 10 & 13 & Conflict & 7 & 5 \\
\hline 4 & Specific investment & 9 & 7 & 14 & Asymetric information & 2 & 7 \\
\hline 5 & Specific human capital & 3 & 4 & 15 & Property & 7 & 7 \\
\hline 6 & responsability multiple & 10 & 9 & 16 & Decision & 3 & 4 \\
\hline 7 & Power & 5 & 2 & 17 & Dispersion of property & 6 & 8 \\
\hline 8 & Legitimacy & 5 & 6 & 18 & Business strategic & 3 & 2 \\
\hline 9 & profit & 1 & 1 & 19 & Business assets & 5 & 8 \\
\hline \multirow[t]{2}{*}{10} & Residual claim & 6 & 3 & & & & \\
\hline & & & & & Totals & 101 & 101 \\
\hline
\end{tabular}


Let $\mathrm{W}=\mathrm{W} \mathrm{l}+\mathrm{W}$ c with $\mathrm{Wl}$ : total weight of the variable influence, Wc: total weight dependence.

The relative importance of variables will be calculated and the results is in Table 16.

Table 16

Relative importance of variables

\begin{tabular}{llll}
\hline Variables & Poids & Variables & Poids \\
\hline Value creating & 22 & Annuity & 6 \\
Opportunity & 4 & Distribution & Conflict \\
Contract node & 12 & Asymetric information \\
Specific investment & 16 & Property & 13 \\
Specific human capital & 7 & Decision & 9 \\
Responsability multiple & 19 & Dispersion of property \\
Low & 7 & Business strategic & 7 \\
Legitimacy & 11 & Business assets & 14 \\
Profit & 2 & & 5 \\
Residual claim & 9 & & 13 \\
\hline
\end{tabular}

At this stage of analysis and based on the study of the relative importance of concepts in cognition of Tunisian players in the company vis-à-vis the stakeholder approach of corporate governance, it is possible to forward the following conclusions: Actors perceive the partnership approach of corporate governance at the concepts of "value creation", "multiple liability. ", " Dispersion of ownership ". But the distribution of the point cloud variables, one can distinguish the first quadrant which includes the most prominent concepts in the dynamics of thought of the actors. For the actors of that organization, the notion of "conflict" is the most dominant in their cognitions reflecting an intention based on a partnership approach based conflicts of interest. The design they make the partnership approach is through different logics: one based on the value of logic of agency and that based on the valuation of a productive logic value. The logic of agency can be explained by the concept of ownership; the conflict is rooted in the possibility of agent behavior (leader) not in the interests of the principal (shareholder). We can now common practice for challenging all power, both in its exercise of its legitimacy.

The logic of productive value is explained by the notion of value creation, we find the idea that the firm is the headquarters of the opposition between different logical organization of the firm consists of two dimensions: the organization of production which function is efficient and productive commercial organization whose function is to value the assets of the company by buying and selling. These two types of functions performed by the respective actors of the firm, may conflict because they do not establish the same criteria for evaluating economic efficiency.

\section{References}

Alexander, R. J. (2000). Culture and pedagogy: international comparisons in primary education. Oxford: Blackwell.

Allouche, J., \& Amann B. (2002). L'actionnaire dirigeant de l'entreprise familiale. Revue française de gestion, 141, 109-130.

AUDET, M. (1994). Plasticité, instrumentalité et réflexivité, dans P. Cossette (dir.), Cartes cognitives et organisations, Collection «Sciences de l'administration», Québec/Paris : Les Presses de l'Université Laval/Éditions ESKA, 187-198.

Berle, A.A. Jr., \& Means, G. C.(1932). Fine Modern Corporation and Private Property. Macmillan, New York.

Blair M. M. (1995). Ownership and Control: Rethinking Corporate Governance for the Twenty-First Century, Brookings Institution, Washington.

Bougon, M.G., \& Komocar, J.M. (1994a). Les cartes cognitives composites. Une théorie holistique et dynamique des organisations", dans P. Cossette (dir.), Cartes cognitives et organisations, Collection "Sciences de l'administration".Québec/Paris: Les Presses de l'Université Laval/Éditions ESKA, 37-56. 
Bougon, M. G., Weick, K. E., \& Binkhorst, D. (1977) .Cognition in Organizations: An Analysis of the Utrecht Jazz Orchestra. Administrative Science Quarterly, 22(4), 606-639.

Capron, M., \& Quairel-Lanoizelée, F. (2004). Mythes et réalités de l'entreprise responsable Acteurs, enjeux, stratégies. Paris : La Découverte.

Cazal D., \& Dietrich A. (2005). RSE : parties prenantes et partis pris », VIIème Université de printemps de l'Audit Social, Marrakech.

Charreaux, G., \& Desbrières, P. (1998). Gouvernance des entreprises : valeur partenariale contre valeur actionariale. Revue Finance Contrôle Stratégie, Editions Economica, 1(2), 57-88.

Cossette, P. (1994). Les cartes cognitives au service de l'étude des organisations. dans P. Cossette (dir.), Cartes cognitives et organisations, Collection "Sciences de l'administration", Québec/Paris: Les Presses de l'Université Laval/Éditions ESKA, 3-12.

Cossette, P. (2004). L'Organisation : une perspective cognitiviste, collection "Sciences de l'administration », Québec : Presses de l’Université Laval.

Cossette, P., Audet, M. (1994). Qu'est-ce qu'une carte cognitive?", dans P. Cossette (dir.), Cartes cognitives et organisations, Collection "Sciences de l'administration", Québec/Paris : Les Presses de l’Université Laval/Éditions ESKA, 13-33.

Demsetz, H. (1998). L'Economie de la Firme. Sept Commentaires Critiques. Traduction de

The economics of the Business Firm - Seven Critical Commentaries. Traduction de J.C. Papillon,

Editions Management et société (EMS), Paris, 250.

Eden, C., \& Ackermann, F. (1998). Making Strategy: The Journey of Strategic Management.Sage Publications, Londres.

Ford, J. D., \& Hegarty, W. H. (1984). Decision makers' beliefs about the causes and effects of structure: An exploratory study. Academy of Management Journal, 27(2), 271-291.

Freeman, R. E. (1984). Strategic Management: A Stakeholder Approach, Pitman. Boston.

Freeman, R. E., \& Reed, D. L.(1983). Stockholders and stakeholders: A new perspective on corporate governance. California Management Review,25(3, 88-106.

Friedman M. (1970).The Social Responsibility of Business is to increase its profits. New York Times Magazine, September 13.

Gérard, C. (1997). L'entreprise publique est-elle nécessairement moins efficace? Working Papers FARGO 0970901

Gérard C. (2000). Nouvelle économie et gouvernance. Working Papers FARGO 1000801.

Gérard, C. (2002). Au-delà de l'approche juridico-financière:le rôle cognitif des actionnaires et ses conséquences sur l'analyse de la structure de propriété et de la gouvernance. Working Papers FARGO 020701.

Gérard, C. (2006). La valeur partenariale:vers une mesure opérationnelle... Stakeholder value: towards an operational measure. Working Papers FARGO 1061103.

Langfiel-Smith, K. (1992). Exploring the need for a shared cognitive map. Journal of Management Studies, 29(3), 349-368.

Komocar, J.M. (1994). Cartes causales d'un milieu de travail. In P. Cossette (Ed.),Cartes cognitives et organisations, éd. Eska, 155-184.

Morck, R., Shleifer, A., \& Vishny, R.W. (1988). Characteristics of targets of hostile and friendiy takeovers, in: A.J. Auerbach, ed., Corporate takeovers: Causes and consequences. University of Chicago Press, Chicago, IL, 101-129.

Rajan, R. G., \& Zingales, L. (1998). Financial dependence and growth. American Economic Review, 88(3), 559-86.

Weick. K. E. (1969). The social psychology of organizing. Reading, Massachusetts: AddisonWelsey.

Weiss, J.W. (1998). Business Ethics, a Stakeholder and Issues Management Approach, 2ème edition. Dryen Press, Philadelphie. 
Appendix

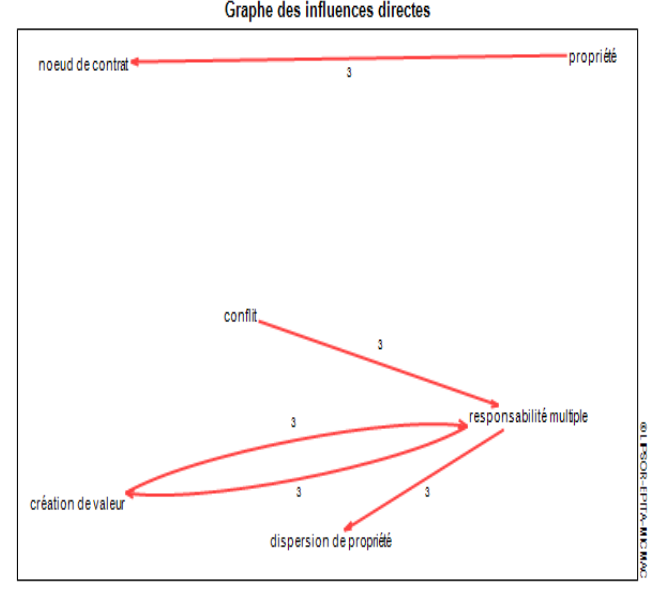

- Influences les plus faibles

- Infiuences faibles

- Infuences moyennes

- Influences les plus impottantes.

Fig. Direct infuences graph

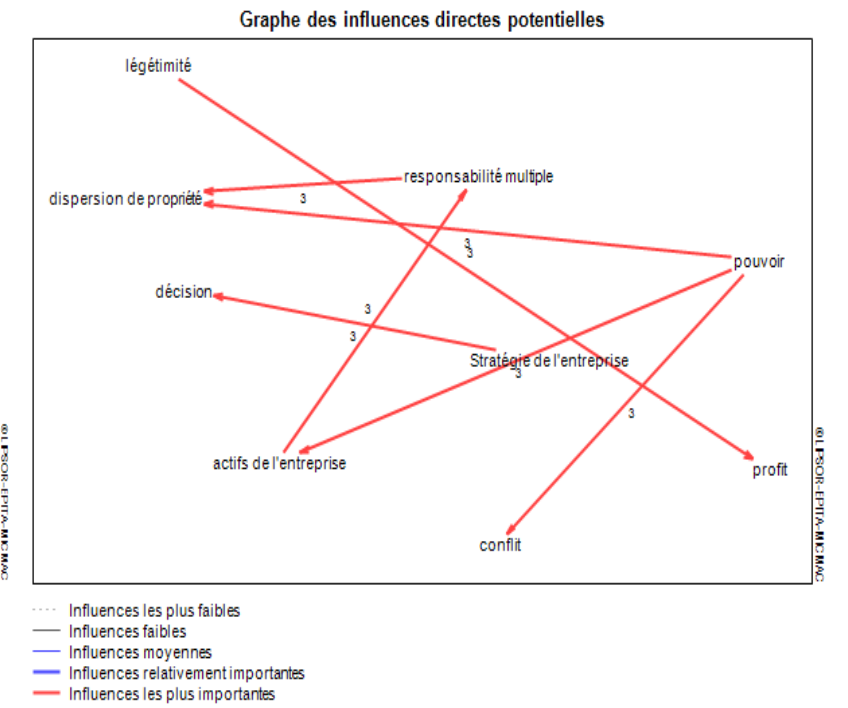

Fig. Direct potential influences graph

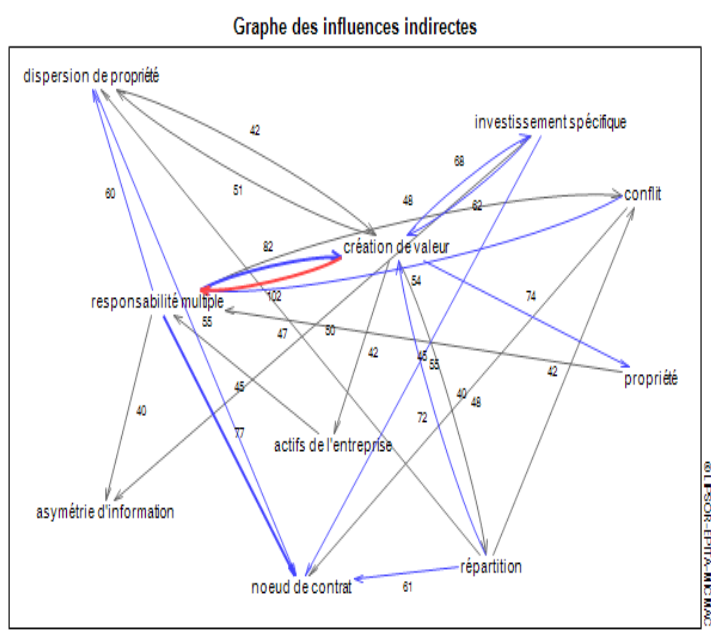

Influences les plus faible

- Influences faibles

- Influences relativementimportantes

- Influences relativementimportast

Fig. Indirect influences graph

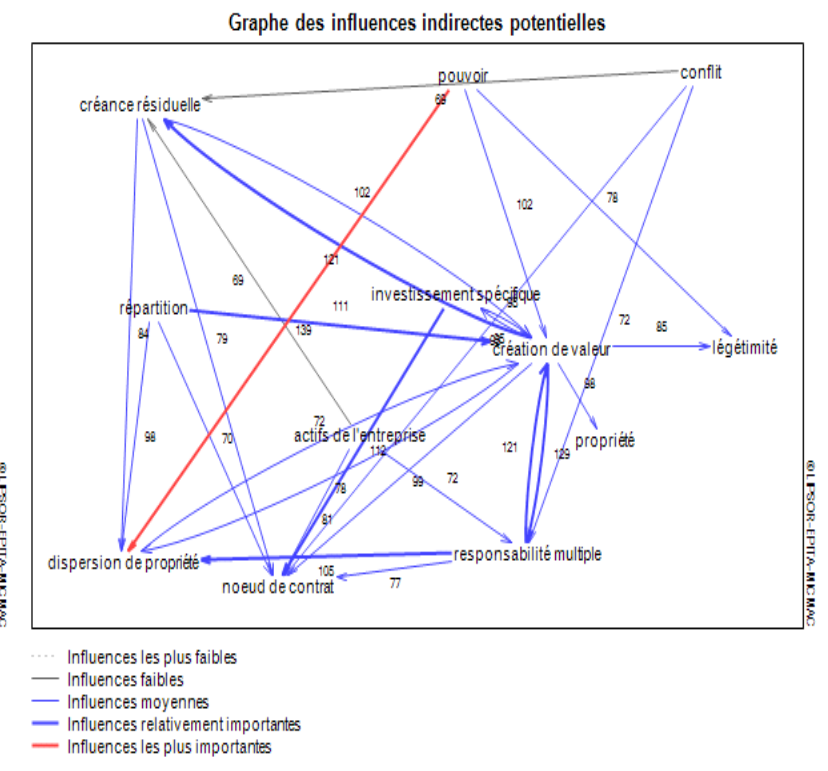

Fig. Indirect potential influences graph 